\title{
Pandangan Tokoh Masyarakat terhadap Pernikahan Dini pada Remaja Etnis Melayu di Kota Palembang
}

\author{
Desliana $^{1 *}$, Duski Ibrahim ${ }^{1}$, Muhammad Adil ${ }^{1}$ \\ ${ }^{1}$ UIN Raden Fatah Palembang, Indonesia
}

\begin{abstract}
Abstrak: Penelitian ini bertujuan untuk menganalisis gejala pernikahan usia dini, pandangan tokoh pada etnis Melayu Palembang serta pemecahan masalahnya. Penelitian ini merupakan penelitian lapangan dalam ranah budaya dengan pendekatan fenomonelogi. Dalam menjaring data digunakan pendekatan deskriptif kualitatif. Data ini dikumpulkan dengan teknik observasi, wawancara dan studi dokumentasi. Penelitian ini menemukan bahwa pertama, angka pernikahan dini di Kota Palembang terus mengalami peningkatan dari tahun ke tahun yang disebabkan berbagai faktor di antaranya ekonomi rendah dan terjadinya kehamilan di luar pernikahan. Kedua, tokoh masyarakat berpandangan bahwa pernikahan merupakan perintah Allah Swt. dan perintah Rasul. Dalam Islam, batas usia diperbolehkannya menikah tidak dijelaskan secara rinci tetapi Islam menyaratkan adanya kesiapan fisik dan mental. Dan ketiga, dengan pembinaan nilai-nilai moral dan optimalisasi fungsi kekerabatan melalui fungsi keagamaan, sosial budaya, cinta, perlindungan, reproduksi, sosialisasi dan pendidikan, ekonomi, dan bina lingkungan diharapkan dapat mencegah terjadinya pernikahan dini. Selanjutnya upaya pemerintah untuk mengurangi pernikahan usia muda sangat ditentukan oleh penguatan kerjasama dengan lembaga legislatif, eksekutif, dan yudikatif, serta melibatkan partisipasi masyarakat, media dan dunia usaha secara terstruktur, holistik, dan integratif di Indonesia.
\end{abstract}

Kata Kunci: pernikahan dini, etnis melayu, nilai keislaman

\begin{abstract}
This study aims to analyze the symptoms of early marriage, the views of figures on the Palembang Malay ethnicity and solving the problem. This research is a field research in the cultural realm with a phenomonological approach. In collecting data, a qualitative descriptive approach was used. This data was collected by means of observation, interviews and documentation studies. This study found that first, the number of early marriages in the city of Palembang continues to increase from year to year due to various factors including the low economy and the occurrence of pregnancies outside of marriage. Second, community leaders are of the view that marriage is an order from Allah SWT. and the Prophet's orders. In Islam, the age limit for marriage is not explained in detail, but Islam requires physical and mental readiness. And third, by fostering moral values and optimizing the function of kinship through religious, socio-cultural, love, protection, reproduction, socialization and education, economic and environmental functions, it is hoped that early marriage can be prevented. Furthermore, the government's efforts to reduce early marriage are largely determined by strengthening cooperation with legislative, executive, and judicial institutions, as well as involving the participation of the public, media and business in a structured, holistic, and integrative way in Indonesia.
\end{abstract}

Keywords: early marriage, Malay ethnicity, Islamic value

\footnotetext{
${ }^{*}$ Corresponding Author: Desliana (desliana1021@gmail.com). UIN Raden Fatah Palembang, Indonesia
}

p-ISSN 1412-1697; e-ISSN 2477-3816

http://jurnal.radenfatah.ac.id/index.php/intizar 


\section{Pendahuluan}

Pernikahan dini merupakan fenomena sosial yang terjadi di banyak daerah. Fenomena pernikahan dini ibarat gunung es yang hanya muncul di sebagian kecil di permukaan, sangat sedikit terekspos di ruang publik, namun nyatanya banyak terjadi di masyarakat luas. Bila kita menelusuri akar sejarah pernikahan dini di Indonesia, khususnya di pulau Jawa, sebenarnya sudah menjadi hal yang biasa dilakukan nenek moyang kita. Dalam konteksnya, terdapat stigma negatif jika seorang perempuan terlambat menikah.

Wacana pernikahan dini sebenarnya bukanlah hal baru untuk dibahas. Isu ini kerap diangkat menjadi topik utama dalam berbagai diskusi. Meski begitu, masalah ini selalu menarik keinginan anak muda untuk lebih mendalami tentang apa dan bagaimana pernikahan dini. Istilah pernikahan dini adalah istilah yang relatif kontemporer. Dini biasanya dikaitkan dengan waktu, yang merupakan permulaan. Kebalikannya adalah pernikahan yang berakhir. Bagi masyarakat yang hidup di awal abad ke-20 atau lebih awal, pernikahan dini merupakan hal yang lumrah, bukan sesuatu yang dianggap tabu dan tidak penting untuk dimunculkan. Seiring dengan perkembangan zaman, image yang berkembang di masyarakat justru sebaliknya. Arus globalisasi yang berjalan sangat cepat telah merubah paradigma berpikir masyarakat luas. Pernikahan di usia yang masih sangat muda dianggap tabu, karena dinilai memiliki banyak dampak negatif, terutama bagi perempuan. Meski begitu, fenomena pernikahan dini masih sering terjadi, terutama di wilayah yang tingkat kesadaran pendidikannya mayoritas masih tergolong rendah.

Dalam Hukum Islam tujuan pernikahan telah tertera dengan jelas sebagaimana dalam surat anNisa ayat dan al-Rum ayat 21. Pernikahan adalah sunah Rasulullah Saw., diikuti oleh kaum muslimin. Rasulullah Saw. sangat menganjurkan pernikahan bagi seorang telah mampu melaksanakannya, dan barang siapa yang tidak melaksanakan pernikahan, sedang ia telah mampu secara lahir dan batin, berarti ia telah mengabaikan sunah Rasulullah Saw. Sebagaimana Hadis yang diriwayatkan oleh Imam Bukhari dan Imam Muslim bahwa generasi muda yang telah mampu berkeluarga maka menikahlah karena menikah dapat menundukkan pandangan dan memelihara kemaluan. Jika belum mampu, maka hendaknya berpuasa.

Hadis tersebut menegaskan bahwa Islam menganjurkan seseorang untuk berumah tangga, karena dari aspek batin orang dapat mencapainya melalui berkeluarga yang baik. Apabila seseorang ingin melaksanakan pernikahan berarti ia sudah siap menerima dalam segala hal, baik fisik maupun mental untuk menjalani bahtera rumah tangga, Dalam hukum islam tidak terdapat kaidah-kaidah yang sifatnya menentukan batas umur pernikahan. Jadi berdasakan umur Islam pada dasarnya semua tindakan umur dapat melakukan ikatan pernikahan, hal ini sesuai dengan tindakan Nabi Muhammad Saw yang telah menikahi Aisyah pada umur 6 tahun dan tinggal bersama Nabi saat Aisyah berusia 9 tahun.

Dalam hukum adat pada umumnya tidak mengatur tentang batas umur untuk melaksanakan pernikahan, hal ini berarti hukum adat membolehkan pernikahan untuk semua umur asal sudah dewasa. Kedewasaan seseorang menurut hukum adat diukur dengantanda tanda fisik yaitu apabila wanita sudah haid (datang bulan), buah dada menonjol berarti sudah dewasa, sedang bagi pria ukurannya dapat dilihat dari perubahan suara, parubahan fisik, sudah mengeluarkan air mani atau sudah mempunyai nafsu seks. 
Sesungguhnya, "amat sulit menentukan umur berapa sebaiknya seseorang menikah atau berapa batas umur untuk dapat di sebut sudah matang atau cukup dewasa untuk berkeluarga" (Supriyadi, 2011). Setiap anak yang puber atau yang sudah matang adalah tidak sama dengan kematangan usia berbeda satu dengan lainnya yang mana pada kebiasaannya dalam hal kecepatan waktu dewasa dan kelambatan masa pendewasaannya yang disebabkan oleh kondisi rumah dimana berada dan lingkungan sekitarnya, juga disebabkan oleh faktor finansial, pendidikan dan sosial rumah tangga. Batasan pubertas dalam Islam juga tidak bisa dikatakan "dewasa" tetapi merupakan awal dari kedewasaan.

Sementara itu hukum positif yang mengatur tentang pernikahan tertuang dalam UndangUndang Republik Indonesia Nomor 16 Tahun 2019 tentang Perubahan atas Undang-Undang Nomor 1 Tahun 1974 tentang Pernikahan. Adapun batas usia pernikahan diatur dalam Pasal 7, pernikahanhanya diizinkan apabila pria dan wanita sudah mencapai umur 19 (sembilan belas) tahun. Dalam hal terjadi penyimpangan terhadap ketentuan umur sebagaimana dimaksud di atas, orang tua pihak pria dan/atau orang tua pihak wanita dapat meminta dispensasi kepada Pengadilan dengan alasan sangat mendesak disertai bukti-bukti pendukung yang cukup. Pemberian dispensasi oleh Pengadilan sebagaimana dimaksud di atas wajib mendengarkan pendapat kedua belah calon mempelai yang akan melangsungkan pernikahan.

Kebijakan pemerintah dalam menetapkan batas usia minimal untuk menikah tentunya telah melalui berbagai proses dan pertimbangan. Hal ini agar kedua belah pihak benar-benar siap dan matang dari segi fisik, psikis dan mental. Lebih lanjut dijelaskan dalam Pasal 6 ayat 2 UU Pernikahan "bahwa untuk menikah dengan orang yang belum berusia 21 tahun harus mendapat izin dari kedua orang tua. Namun dalam praktiknya, di masyarakat secara umum masih banyak yang menikah di usia muda atau di bawah umur".

Data statistik secara nasional menunjukkan bahwa, pernikahan dini pada 2018, dari total 267 juta penduduk Indonesia, 11.2 persen wanita menikah di umur 20-24 tahun. Sebaliknya pernikahan wanita yang berumur kurang dari 17 tahun sebesar 4,8 persen. Pernikahan anak di dasar umur 16 tahun dekat 1,8 persen serta persentase pernikahan anak berumur kurang dari 15 tahun beberapa 0,6 persen. Secara garis besar, satu dari 9 anak wanita umur kurang dari 18 tahun menikah muda. Bagi informasi Tubuh Pusat Statistik, pernikahan anak berumur 17 tahun ke dasar sangat besar ditemui di Kalimantan Selatan, ialah sebesar 27,82 persen.

Berdasarkan informasi Badan Kependudukan dan Keluarga Berencana Nasional (BKKBN) Provinsi Sumatera Selatan, Kabupaten Musi Rawas ialah wilayah paling tinggi yang melaksanakan pernikahan umur dini. Di Palembang masih ditemui pernikahan dini, dalam 2 tahun terakhir ini rata- rata terjadi pernikahan dini sebanyak 10 (sepuluh) pasang yang melakukan pernikahan dini sesama anak yang masih sekolah yang mempunyai permasalahan pernikahan dini (Hadjar, 2020). Dari permasalahan tersebut berarti ada 60 (enam puluh) orang yang menpunyai permasalahan diakibatkan pernikahan ini, kenapa demikian, dapat diuraikan bahwa setiap anak yang mempunyai masalah, secara langsung melibatkan orang tua masing-masing yaitu ayah dan ibu anak perempuan, begitu juga dengan ayah dan ibu anak laki-laki yang melakukan pernikahan dini. Dikenal angka pernikahan dini di Sumsel masih besar, dari 1.000 kelahiran balita, sebanyak 22, 3\% merupakan balita yang dilahirkan dari perempuan 
yang melakukan pernikahan di umur 15- 19 tahun (Rahmawati, 2020).

Padahal, usia ideal bagi perempuan untuk menikah adalah 21-25 tahun, sedangkan untuk lakilaki adalah 25-28 tahun. Karena pada usia tersebut organ-organ dalam diri seorang wanita sudah berkembang dengan baik dan kuat, serta dianggap matang secara psikologis untuk menjadi calon orang tua bagi anaknya. Sedangkan kondisi fisik dan psikologis laki-laki pada usia tersebut cukup kuat untuk dapat menopang kehidupan keluarga dan melindunginya secara psikologis, emosional, ekonomi dan sosial.

Pernikahan dini berdampak pada kesehatan reproduksi anak perempuan. Gadis berusia 10-14 tahun lima kali lebih mungkin meninggal dibandingkan wanita berusia 20-25 tahun. Sedangkan anak usia 15-19 tahun dua kali lipatnya. Dadang Hawari, seorang psikiater menyatakan bahwa secara psikologis dan biologis, seseorang sudah dewasa untuk berproduksi dan bertanggung jawab sebagai ibu rumah tangga antara usia 20-25 tahun untuk wanita atau 25 hingga 30 tahun untuk pria. Sebelum usia tersebut, dianggap terlalu cepat, yang disebutnya precock, yaitu matang sebelum waktunya (Rifiani, 2011). Kondisi yang berkembang memberikan gambaran konkrit bahwa pernikahan yang dilaksanakan tanpa kesiapan dan pertimbangan yang matang dari satu sisi dapat menunjukkan sikap tidak menghargai makna pernikahan bahkan lebih jauh dapat merupakan penyalahgunaan pernikahan itu sendiri selama itu terjadi. dianggap suci oleh agama.

Secara umum beberapa orang yang menikah di usia muda dipengaruhi oleh beberapa faktor, yaitu: Pernikahan dini terjadi karena keadaan ekonomi keluarga yang berada di bawah garis kemiskinan, sehingga jika seorang anak perempuan masih sangat muda sudah cukup untuk meringankan. beban orang tuanya. terutama dari sisi ekonomi. Para orang tua, anak-anak, dan orangorang dengan tingkat kesadaran pendidikan yang rendah dikhawatirkan akan mendapat aib karena anak perempuannya sudah berpacaran dengan lakilaki jika tidak segera dinikahinya. Gencarnya media massa, baik cetak maupun elektronik, khususnya internet yang tidak dapat dikendalikan dalam batas yang aman untuk konsumsi publik yang mengekspos pornografi dan adegan-adegan yang tidak pantas untuk ditayangkan secara umum, menyebabkan semakin banyaknya remaja modern yang terjerumus ke dalam ruang lingkup "masyarakat permisif' bagaimanapun yang mereka inginkan dan pernikahan di usia muda terjadi karena orang tua takut anak-anaknya akan menjadi perawan tua jika mereka tidak segera menerima lamaran dari pria yang melamarnya (Rifiani, 2011).

Dampak pernikahan dini dapat dinilai dari berbagai sudut pandang, yaitu: dampak terhadap hukum pernikahan dini jika dilakukan berarti mengabaikan beberapa hukum yang telah ditetapkan yang terdapat pada Undang- Undang No. 1 Tahun 1974 tentang Pernikahan pasal 7 ayat 1 dan pasal 16 ayat 2. Ditinjau dari dampak biologis dan psikologis yang dapat kita ketahui secara umum, secara biologis organ reproduksi anak yang baru mencapai pubertas masih dalam proses mencapai kematangan sehingga belum siap untuk berhubungan seks dengan lawan jenis. seks, terutama jika mereka hamil dan melahirkan. Jika dipaksakan, yang terjadi justru akan menjadi trauma, robekan yang parah dan infeksi yang akan membahayakan organ reproduksi hingga membahayakan nyawa anak. Perlu dipertanyakan apakah hubungan seksual tersebut didasarkan pada persamaan hak reproduksi antara istri dan suami atau apakah ada kekerasan seksual dan pemaksaan terhadap anak. 
Secara psikologis anak belum siap dan kurang memahami hubungan seksual, sehingga akan menimbulkan trauma psikologis yang berkepanjangan pada jiwa anak yang sulit disembuhkan. Dampak sosial dan perilaku seksual, fenomena sosial ini berkaitan dengan faktor sosial budaya dalam masyarakatyang cenderung memposisikan wanita sebagai pelengkap kehidupan laki-laki saja. Kondisi ini hanya akan melestarikan budaya patriarkhi yang kebanyakan hanya akan melahirkan kekerasan dan menyisakan kepedihan bagi perempuan.

Dari uraian di atas, walaupun jumlah pernikahan usia dini di Palembang cukup sedikit, namun sangat menarik untuk dikaji mengingat bahwa Palembang merupakan rumpun etnis Melayu. Sebelumnya telah dilakukan beberapa penelitian seperti yang dilakukan Jeki Sepriady (2018), Yosi Malasar dan Cecep Darmawan (2017), Iwan, Agus dan Supriadi (2015), Asmidar dan Yoskar Kadarisman (2015), dan Muhammad Alif (2020).

Etnis Melayu Palembang atau yang lebih dikenal dengan "Suku Palembang" adalah salah satu suku Melayu yang berdomisili di kota Palembang dan sekitarnya. Selain berdomisili di Kota Palembang, penyebaran Melayu Palembang terdapat pada Kaum kerabat Ogan, Lubai, Rambang, Cambai, Pegagan, Lembak, Lintang, Kikim, Gumay, Besemah, Enim, Semende, Kisam dan Lematang (Pedia, 2019)

Etnis Melayu Palembang di Palembang semakin lama semakin berkurang, tetapi di Tepian Sungai Musi masih banyak ditemukan suku Palembang. Dalam kesehariannya, suku Palembang berbicara dalam bahasa Palembang. Bahasa Palembang sendiri merupakan bagian atau varian dari bahasa Melayu atau sering disebut sebagai bahasa Melayu Palembang. Bahasa
Palembang menggunakan dialek "o" pada akhir setiap kata mirip dengan Bahasa Melayu Jambi dengan Suku Melayu Bengkulu. Suku Melayu Palembang banyak menganut agama Islam, Islam menjadi agama yang dianut sebagaian besar orang Palembang. Sondok piyogo atau dalam bahasa Indonesia berarti "Adat dipangku, syariat dijunjung" merupakan semboyan yang dipegang teguh oleh suku Palembang. Semboyan tersebut bermakna bahwa meskipun mereka sudah mengecap pendidikan tinggi, mereka tetap mempertahankan adat kebiasaan suku Palembang sisanya beragama Budha. Tetapi masih ada juga yang beragama animisme, Beberapa kalangan berpendapat bahwa suku Palembang merupakan hasil dari peleburan bangsa Arab, Tionghoa, suku Jawa dan kelompok-kelompok suku lainnya di Indonesia. Dari 1,2 juta penduduk kota Palembang, 40-50\% adalah suku Palembang mereka juga hidup secara berdamping-dampingan dan damai (Pedia, 2019). Banyak orang Palembang yang masih tinggal di rumah yang didirikan di atas air. Rumah limas menjadi model arsitektur rumah khas Palembang yang kebanyakan didirikan di atas panggung di atas air untuk melindungi dari banjir (Wikiwand, 2020).

\section{Metode}

Jenis penelitian ini merupakan penelitian lapangan dan menggunakan metode penelitian kualitatif dengan pendekatan fenomenologi. Dipilihnya pendekatan fenomenologi dalam penelitian ini karena fenomena pernikahan dini masih terjadi di kota palembang, dalam hal ini melalui tokoh masyarakat akan memberikan solusi, sehingga tingkat pernikahan dini pada remaja etnis melayu dapat teratasi. Pengumpulan data dilakukan melalui observasi partisipasi, wawancara mendalam, dan studi dokumentasi. Kemudian yang terakhir teknik analisis data yang digunakan dalam 
penelitian ini mengacu pada konsep Miles and Huberman interactive model, adapun model interaktif yaitu: pengumpulan data, reduksi data, penyajian data dan penarikan kesimpulan.

\section{Hasil dan Pembahasan}

\section{Fenomena Pernikahan Dini pada Remaja Etnis Melayu di Kota Palembang}

Masalah pernikahan usia dini di saat ini telah jadi kasus dunia. Informasi UNICEF menampilkan lebih dari 700 juta wanita menikah di kala umur kanak-kanak apalagi 1 dari 3 di antara wanita yang menikah usia dini menikah pada umur saat sebelum 15 tahun (Statistik \& UNICEF, 2016). Data BKKBN 2014 menujukkan kalau jumlah anak muda di Indonesia telah mencapai 74 juta jiwa, dari jumlah tersebut, 59\% berusia 15-19 tahun telah menikah (Guilbert, 2013). Pernikahan dini di Indonesia menduduki peringkat ke 37 di dunia pada tahun 2010, perihal ini berarti Indonesia tercantum sebagai negeri dengan presentase pernikahan dini tinggi di dunia. Informasi SDKI (2012) mengatakan kalau 340.000 anak wanita menikah pada umur dini tiap tahunnya.

The United Nations Childrens Fund (UNICEF) pada tahun 2013, Indonesia jadi negeri dengan angka pernikahan anak paling tinggi ketujuh di dunia. Berikutnya, informasi dari Survei Sosial Ekonomi Nasional (Susenas) tahun 2015, melaporkan kalau sebanyak 1 dari 4 anak wanita di dasar umur 18 tahun sempat menikah. Pada tahun 2017, sebanyak 2 dari 5 anak wanita umur 10 sampai 17 tahun sempat menikah. Sesuai angka tersebut, menampilkan kalau Indonesia masih butuh menaruh atensi lebih pada permasalahan pernikahan usia dini. "Angka pernikahan anak di Indonesia ini masih sangat memprihatinkan. Dari segala negeri anggota ASEAN, Indonesia terdapat di peringkat 2" (Leny, 2020), Pada 2018, dari total
267 juta penduduk Indonesia, 11,2 persen wanita menikah di umur 20-24 tahun. Sebaliknya pernikahan wanita yang berumur kurang dari 17 tahun sebesar 4,8 persen. Pernikahan anak di bawah umur 16 tahun sekitar 1,8 persen serta persentase pernikahan anak berumur kurang dari 15 tahun sejumlah 0,6 persen. Secara akumulasi, satu dari 9 anak wanita umur kurang dari 18 tahun menikah muda (Rahmawati, 2020).

Persentase pernikahan umur muda (dini) di Indonesia bertambah. Badan Pusat Statistik (BPS) merilis angka $15,66 \%$ buat persentase pernikahan dini di Indonesia pada 2018. Angka tersebut bertambah dari $14,18 \%$ pada 2017 . Peningkatan persentase pernikahan dini tersebut ialah catatan tertentu untuk pemerintah yang tengah berupaya membetulkan Indeks Pembangunan Manusia (IPM) (Indonesia baik, 2020).

Pernikahan dini di beberapa negara dianggap sebagai solusi alternatif untuk masalah kemiskinan keluarga. Keluarga miskin dinilai dapat terbantu ketika anak perempuannya menikah dini sehingga dapat membantu meringankan beban ekonomi keluarga. Purnomo mengatakan bahwa selain motif ekonomi, pernikahan dini telah dicoba dengan motif hubungan yang sangat erat antara perempuan dan teman laki-laki, juga memiliki hubungan intim (seksual), terbentuknya kehamilan pranikah, kekhawatiran seperti perawan tua, dan kemudahan berpacaran. Akses ke konten media seksualitas (Satriyandari \& Utami, 2020).

Fenomena tersebut juga terjadi pada remaja etnis Melayu di Palembang di antaranya kecamatan Seberang Ulu I pada tahun 2017 terdapat 139 kasus dari 1160, tahun 2018 terdapat 197 kasus dari 1229 (Triningsi, 2020). Sedangkan di kecamatan Ilir Timur II pada tahun 2017 terdapat 65 kasus dari 1092 dan pada tahun 2018 terdapat 81 kasus dari 1111 (Rospita, 2020). Di kecamatan Sukarami pada 
tahun 2017 terdapat 83 kasus dari 1040 dan tahun 2018 terdapat 104 kasus dari 1258 (Yuhanis, 2020). Di Palembang masih ditemui pernikahan dini, walaupun jumlahnya sedikit. Bersumber pada datanya, sudah terjalin 2-4 pernikahan dini yang terjadi pada kanak-kanak di Palembang dalam setahun. Sebaliknya dalam 2 tahun terakhir, jumlahnya masih tidak lebih dari 10 permasalahan pernikahan dini” (Hadjar, 2020).

Berikutnya Kepala Dinas Perlindungan Perempuan, Perlindungan Anak serta Pemberdayaan Manusia (PPPAPM) Palembang menyatakan pernikahan dini, lebih banyak didera oleh kanak-kanak putus sekolah. Sebab itu, Forum Anak Palembang melaksanakan sosialisasi kepada golongan kanak-kanak yang hendak berperan bagaikan pelapor sekalian pelopor untuk program komunikasi, edukasi dan informasi tentang pernikahan dini. Sosialisasi hendak mengaitkan kanak- kanak sebagai media pendidikan bersama di golongan mereka (anak-anak). Rata- rata temuan permasalahan pernikahan dini terjadi sebab anak perempuannya telah berbadan dua (hamil). Keadaan ini memanglah susah serta memang wajib dinikahkan, sebab pihak keluarga berkeinginan terdapatnya tanggungjawab atas keadaan tersebut, temuan kanak-kanak yang hadapi pernikahan dini lebih banyak pada keluarga dengan ekonomi menengah ke bawah. Perluasan informasi akan sangat dibutuhkan guna menjelaskan adanya dampak pernikahan dini paling utama dari sisi kesehatan wanita. Pernikahan dini akan rentan pada kesehatan reproduksi anak perempuan. Dikala pilihannya supaya dinikahkan, pihak keluarga pula mengingat keselamatan balita serta ibunya, termasuk sisi agama kala anak harus digugurkan (Hadjar, 2020).

Hasil penelusuran informasi dari dinas ataupun instansi dalam 3 tahun terakhir ialah di
Kantor Urusan Agama (KUA) Kota Palembang peristiwa nikah dini sekitar $10 \%$, serta terdapat sekitar 30\% masalah pernikahan isbat dari tahun ke tahun, perihal ini dibuktikan dengan pengajuan masalah (perkara) pernikahan, permohonan akad nikah diperuntukan buat meminta supaya pernikahannya dilegalkan sebab pernikahan dini tanpa pencatatan ataupun tanpa catatan administrasi oleh seseorang pencatat pernikahan.

Permohonan nikah ini dibuat untuk mengajukan gugatan cerai, karena perceraian hanya bisa dilakukan jika bisa menunjukkan buku akta nikah yang sah, sedangkan pasangan yang mengajukan dispensasi nikah dalam tiga tahun terakhir tidak banyak kasus yang terjadi tiap tahunnya. mulai 2017-2019 (Irfan, 2019). Adapun rekapitulasi jumlah pernikahan menurut kelompok umur dapat dilihat pada tabel 1, 2, dan 3 .

Tabel 1. Rekapitulasi Jumlah Pernikahan Menurut Kelompok Umur di Kecamatan Ilir Timur II

\begin{tabular}{|c|c|c|c|c|}
\hline \multirow{2}{*}{ Tahun } & \multicolumn{3}{|c|}{ Kelompok Umur } & \multirow{2}{*}{ Jumlah } \\
\cline { 2 - 4 } & $\begin{array}{c}<20 \\
\text { Tahun }\end{array}$ & $\begin{array}{c}20 \text { s/d } \\
30 \\
\text { Tahun }\end{array}$ & $\begin{array}{c}>30 \\
\text { Tahun }\end{array}$ & \\
\hline 2017 & 65 & 789 & 29 & 1092 \\
\hline 2018 & 81 & 821 & 09 & 1111 \\
\hline
\end{tabular}

Tabel 2. Rekapitulasi Jumlah Pernikahan Menurut Kelompok Umur di Kecamatan Sukarame

\begin{tabular}{|c|c|c|c|c|}
\hline \multirow{2}{*}{ Tahun } & \multicolumn{3}{|c|}{ Kelompok Umur } & \multirow{2}{*}{ Jumlah } \\
\cline { 2 - 4 } & $\begin{array}{c}<20 \\
\text { Tahun }\end{array}$ & $\begin{array}{c}20 \mathrm{~s} / \mathrm{d} \\
30 \\
\text { Tahun }\end{array}$ & $\begin{array}{c}>30 \\
\text { Tahun }\end{array}$ & \\
\hline 2017 & 83 & 898 & 159 & 1140 \\
\hline 2018 & 104 & 967 & 188 & 1259 \\
\hline
\end{tabular}


Tabel 3. Rekapitulasi Jumlah Pernikahan Menurut Kelompok Umur di Kecamatan Seberang Ulu I

\begin{tabular}{|c|c|c|c|c|}
\hline \multirow{2}{*}{ Tahun } & \multicolumn{3}{|c|}{ Kelompok Umur } & \multirow{2}{*}{ Jumlah } \\
\cline { 2 - 4 } & $\begin{array}{c}<20 \\
\text { Tahun }\end{array}$ & $\begin{array}{c}20 \text { s/d } 30 \\
\text { Tahun }\end{array}$ & $\begin{array}{c}>30 \\
\text { Tahun }\end{array}$ & \\
\hline 2017 & 139 & 794 & 227 & 1160 \\
\hline 2018 & 197 & 814 & 218 & 1229 \\
\hline
\end{tabular}

Berdasarkan data di atas, jumlah tertinggi yang melakukan pernikahan di bawah Usia 20 tahun pada 3 (tiga) Kecamatan di Kota Palembang Tahun 2017 dan 2018 dapat dilihat pada tabel 4.

Tabel 4. Pernikahan Di Bawah Usia 20 Tahun pada 3 (tiga) Kecamatan di Kota Palembang

\begin{tabular}{|c|c|c|}
\hline \multirow{2}{*}{ Kecamatan } & \multicolumn{2}{|c|}{ Tahun } \\
\cline { 2 - 3 } & $\mathbf{2 0 1 7}$ & $\mathbf{2 0 1 8}$ \\
\hline SU I & 139 & 197 \\
\hline Sukarame & 83 & 104 \\
\hline Ilir Timur II & 65 & 81 \\
\hline
\end{tabular}

Sesuai data di atas jelas terlihat kecamatan yang paling tinggi penduduknya yang melakukan pernikahan di bawah usia 20 tahun yaitu Kecamatan Seberang Ulu I, ini sesuai dengan jumlah penduduk yang sebagian besar adalah penduduk asli Etnis Melayu dan juga kepadatan penduduk yang cukup tinggi, dari data diatas terdapat persentase kenaikan sekitar 5 persen, suatu kenaikan yang cukup signifikan.

Pada dasarnya fenomena pernikahan dini yang terjadi di Kota Palembang lebih banyak yang tidak tercatat. Daripada hasil penelusuran di Kantor Urusan Agama (KUA) ataupun petugas pencatatan nikah serta di kantor pengadilan agama serta kantor kelurahan, pada kantor kelurahan ataupun di kantor pengadilan, sebab rata- rata permasalahan tersebut dituntaskan secara adat, baru setelah itu timbul permasalahan bila terjalin perceraian.

Fenomena pernikahan muda terpaut erat dengan tingginya angka perceraian, seperti yang terjadi di Kota Palembang dalam 3 tahun terakhir, pada tahun 2017, bersumber pada rekapitulasi perkara yang diterima di Pengadilan Agama Palembang di wilayah tersebut. Pengadilan Tinggi Agama Kota Palembang periode Januari-Desember 2017. 174 gugatan cerai pria serta 372 gugatan cerai wanita, 28 perkara gugatan nikah, sebaliknya tahun 2018 terdapat 211 masalah cerai serta 435 perceraian, 9 perkara gugatan cerai, Sebaliknya pesan dakwaan pernikahan dari Januari sampai Juli sebanyak 296 permasalahan perceraian, baik gugatan cerai ataupun cerai (Hadjar, 2020).

Berikutnya ada $30 \%$ pelaku masalah pernikahan dini tidak melapor serta tidak membuat pencatatan cocok umur sesungguhnya sehingga tidak dilaporkan. tercatat bagaikan pernikahan di bawah usia sebab meningkat usia ataupun meningkat tua, hasil pernikahan tidak bisa ditunda sebab mereka berbadan dua dulu, serta fenomena ini telah jadi rahasia universal serta pemicu perceraian mereka pada biasanya merupakan tidak terdapatnya tanggung jawab pria., pelecehan berat serta kecemburuan serta apalagi poligami yang tidak sehat (Irfan, 2019).

Maraknya pernikahan di dasar usia bisa dilihat pada permohonan dispensasi nikah sebab calon pengantin wanita berbadan dua saat sebelum menikah. Apalagi informasi BPS sendiri mengatakan kalau $21,75 \%$ anak wanita di perkotaan menikah pada umur di bawah 16 tahun, serta 47,79\% di kawasan pedesaan. Tidak hanya itu, perihal ini bisa dilihat pada budaya warga yang memiliki kecenderungan buat menikah pada umur dini sebab terdapatnya rasa malu untuk orang tua bila anak perempuannya yang telah dikira berusia walaupun belum lumayan usia tidak lekas menikah.

Pergeseran budaya tampaknya telah terjadi di Palembang. Ketentuan tidak tertulis yang ditaati dengan kuat sekarang tampak lebih longgar. Saat 
ini, warga seakan sudah terbiasa melihat pasangan lawan jenis bergandengan tangan, menunggang kuda, apalagi bermesraan di depan umum. Tidak jarang hal-hal tersebut dicoba oleh anak-anak berseragam sekolah. Jika hal ini terjadi terus menerus hingga ingin mengarah pada pergaulan bebas dan kehamilan di luar nikah, yang berlanjut pada pernikahan dini (Iskandar, 2021).

\section{Pernikahan Usia Dini Perspektif Tokoh Agama pada Etnis Melayu di Palembang}

Pada kenyataan di kota Palembang, proses pernikahan berdasarkan usia mengedepankan aspek agama yang belum dipahami secara menyeluruh, sehingga menimbulkan banyak perdebatan di segala aspek, termasuk keterangan beberapa tokoh masyarakat.

Mengacu pada Al-Qur'an serta hadis. Syarat usia tidaklah sesuatu perihal yang absolut, dalam Islam tidak terdapat syarat tentang batas usia dalam pernikahan. Tetapi yang butuh dicermati merupakan kata "sanggup". Kemampuan raga ataupun kesiapan mental, kesiapan jasmani ataupun kesiapan rohani. Bila kesiapan jasmani dalam perihal ini merupakan kesiapan ekonomi belum dapat dipadati, hingga hendaknya dia berpuasa.

Pernikahan dini menurut hukum Islam merujuk surat An-Nisa ayat1 dan hadis yang diriwayatkan Imam Bukhari dan Imam Muslim serta hadis lainnya yang menerangkan tentang pernikahan dengan tujuan pernikahan tersebut cocok dengan apa yang diajarkan oleh hadis serta Al-Qur'an. Permasalahan pernikahan di dasar usia bagi kitab- kitab fikih diperbolehkan walaupun belum baligh yang terutama terdapat walinya ialah wali mujbir, kembali pada iktikad hadis Rasulullah ialah seorang yang hendak menikah wajib berusia serta memiliki kesiapan baik persiapan raga serta mental maupun persiapan pembiayaan dalam artian jika belum sanggup dalam membiyayai hingga dianjurkan buat berpuasa (Kalsum, 2020).

Selaras dengan penuturan di atas kalau mengacu kepada Al-Qur'an, bila seorang berkeinginan untuk menikah serta telah sanggup baik secara raga ataupun psikis, hingga pernikahannya tidak dipermasalahkan walaupun dia masih di bawah batas usia yang ditentukan oleh undang-undang, serta kesiapan ekonomi bagi dia (yang menikah) bila telah menjalani kehidupan setelah pernikahan.

Pernikahan dini mengacu sesuai dengan surat an-Nisa ayat 59. Kalimat ulil amri tersebut mengenakan penyambung huruf wawu bukan athi'u ulil amri, dalam teori bahasa huruf wawu itu huruf 'athof menjajaki kepada kalimat athi'ullah wa athi'urrasul, jadi prioritas utama merupakan taat kepada Allah taat, kepada rasul, dan ulil amri (pemerintah) wajib menjajaki. Hukum positif ialah produk ulil amri sedangkan hukum Allah serta rasulnya ialah manistatho'a (sanggup) jadi kala seseorang pria serta wanita di dasar usia sanggup menikah walaupun tanpa terdapat aspek ataupun indikasi negatif di tingkat sosial serta moral hingga sah-sah saja, sebab mereka telah merasa siap/ sanggup raga serta psikis. Bersumber pada kepada hadits fankihu ma thoba serta manistatho "a minkum. Maksudnya, kita senantiasa mengacu kepada orientasi agama. Al-Qur'an pula mengatakan dalam pesan an-Nur ayat 32 bahwa ayat tersebut tidak terdapat batas usia terhadap pernikahan yang berarti terdapat hasrat buat menikah cocok dengan ketentuan serta syarat syariat Islam (Kalsum, 2020).

Dari beberapa pendapat tokoh-tokoh di atas menjelaskan bahwa dalam Islam usia yang diperbolehkan dalam penerapan nikah tidak disebutkan secara detail, tetapi Islam mensyaratkan adanya kesiapan, baik kesiapan fisik maupun 
kesiapan mental yang artinya kesiapan ekonomi dan kebutuhan biologis. Kedua poin tersebut adalah makna dari ketentuan nikah bagi Islam.

Pernikahan atas dasar usia menurut hukum Islam, dalam pernikahan ada syarat umur tetapi tidak dibatasi atau sudah mencapai kedewasaan, artinya setelah itu perempuan haid dan bagi lakilaki ketika sudah mimpi basah, bagaimanapun juga dalam Islam, syarat pernikahan tidak hanya usia. Harus ada kesiapan. Bagi para ulama terdapat perbandingan komentar, ada yang mengatakan kemampuan untuk melakukan hubungan seksual, ada yang mengatakan kemampuan memenuhi kebutuhan rumah tangga merupakan kebutuhan ekonomi dan biologis, bahkan mempertimbangkan dalil-dalil yang ada. Umur tidak terbatas tetapi dalam amalan yang baik sahabat dan ulama tidak serta merta hanya mendasarkan nikah pada saat dewasa sehingga harus ada kesiapan, nabi sendiri yang menikah itu berumur 25 tahun walaupun pada saat itu beliau belum diangkat menjadi nabi tetapi di sejarah teman-teman yang laki-laki, rata-rata semua perempuan juga. Tapi yang jelas apapun artinya ada kesiapan, kalaupun misalnya tidak menjadi catatan utama tapi nabi tidak sama dengan manusia biasa, ada pengecualiannya atau AlQur'an.

Para tokoh menjelaskan walaupun dalam Islam tidak ditetapkan umur yang tentu, tetapi yang jadi perihal yang sangat berarti merupakan mencermati raga calon mempelai perempuan, apakah dia siap berhubungan suami istri ataupun belum.

Bagi hukum Islam, pernikahan di dasar usia dipulangkan lagi kepada hukum fikih ialah legal asalkan penuhi ketentuan. Pernikahan dalam pemikiran hukum fikih cuma membagikan ketentuan mumayyiz/mumazziyah tidak membagikan batas umur, namun dalam melakukan hubungan seksual wajib memperhatikan jenazah, sebagaimana dicontohkan Nabi yang dinikahi Aisyah sejak usia dini, Nabi tidak langsung bergaul dengannya melainkan menunggu hingga usianya.

Tokoh agama lainnya menjelaskan bahwa jika realitas pernikahan atas dasar usia yang ada pada Etnis Melayu di Palembang cenderung mengabaikan prasyarat mental dan psikis, terutama baligh dan direstui oleh kiai, maka warga tidak mengindahkan hukum pernikahan karena budaya lokalnya. Sebuah referensi yang lahir dari pemikiran yang salah tentang kasus era saat ini (Saifurrahman, 2020).

Tokoh agama Fahrizal (2020) menjelaskan bahwa tidak ada jaminan dalam pernikahan akan bertahan lama kecuali jika didasarkan pada pengetahuan yang cukup tentang rumah tangga tersebut. Di sisi lain, persyaratan usia 16 tahun yang diatur dalam undang-undang pernikahan hanyalah batasan fisik karena tidak ada batasan untuk kedewasaan.

Saifurrahman (2020) menjelaskan bahwa jika terdapat 2 faktor dalam pernikahan yaitu hukum dan hukum, jika pernikahan tersebut mengarah pada suatu kebutuhan yang melanggar undang-undang pernikahan dan Komplasi Hukum Islam mengenai batasan usia, maka dapat ditarik dari konsep ushuliyah yang artinya legal.

Mal An Abdullah menyatakan bahwa remaja Etnis Melayu berarti remaja yang beragama Islam atau muslim, karena melayu identik dengan Islam. Pada dasarnya sah dan boleh saja bila dilakukan sesuai syariat Islam, karena dalam Islam syarat utamanya sudah aqil baligh, aqil baligh bagi orang Indonesia rata-rata pada usia remaja atau belasan tahun, tergantung masa kesuburan seseorang. Namun negara Indonesia sudah punya aturan bahwa usia perempuan menikah umur 16 tahun dan laki-laki umur 19 tahun, dan bila menikah di bawah 
usia 21 tahun pun, harus izin orang tua. Di Kota Palembang sebenarnya tingkat pengetahuan remaja sudah tinggi, mereka tahu batas usia ideal untuk menikah karena sering mendengar mapun di media social serta penyuluhan-penyuluhan yang dilakukan institusi terkait. Akan tetapi seiring dengan pesatnya teknologi dan masa remaja yang keingintahuan mereka sangat besar sehingga apa yang mereka dapat (pengetahuan tentang seksualitas) ingin coba-coba, dan dipraktikkan sehingga pernikahan dini terjadi, akibat suatu hal yang coba-coba (hamil di luar nikah) inilah yang banyak terjadi di kota Palembang sebagai ibukota provinsi yang jelas penduduk remajanya sangat banyak. Jadi di Kota Palembang, pernikahan dini terjadi dikarenakan akibat pergaulan bebas, lingkungan yang kurang peduli, dan peran orang tua yang kurang dominan, maklumlah biasanya di kota besar banyak fasilitas seperti mall, bioskop, dan tempat hiburan. Waktu untuk berkumpul di rumah sangat sedikit. Jadi pernikahan dini di Kota Palembang ini terjadi karena kurang kesadaran atau kurangnya keimanan dalam diri remaja tersebut bukan karena adat budaya (Abdulah, 2020).

Karena kota Palembang ini remajanya sangat banyak, pendidikan agama sudah harus tertanam sejak usia dini sehingga tidak terjadi pernikahan ini, dengan membentengi diri dengan iman yang kuat walaupun Kota Palembang ini metropolis ke depannya mudah-mudahan tidak terjadi atau menurun jumlahnya, karena rumpun Melayu adalah orang yang taat pada ajaran Islam, dan perlu kepedulian dari semua pihak, orang tua, sekolah, lingkungan dan para tokoh serta kebijakan pimpinan daerah (misalnya film yang diputar di bioskop harus mengandung unsur pendidikan untuk remaja) (Abdulah, 2020).

Ayik Ali Idrus menjelaskan bahwa seorang muslim hendaklah menikah setelah akil balig karena kebutuhan biologis, ketidakstabilan jiwa pun biasanya datang pada seseorang setelah aqil baligh, jadi menurut agama Islam tuntunan menikahpun setelah usia aqil baligh. Ukuran aqil baligh setiap manusia lain-lain, tergantung seseorang mendapatkannya, misalnya bagi perempuan ditandai dengan mulai menstruasi dan bagi laki-laki dimulai dengan mimpi basah. Pada umumnya anak perempuan maupun anak laki - laki tanda aqil baligh didapat pada umur belasan tahun, dan menurut ajaran Islam mereka boleh menikah dan sesuai Undang-Undang Nomor 1 Tahun 1974 mengatur bahwa umur anak perempuan boleh menikah pada usia 16 Tahun, sedangkan laki-laki berumur 19 tahun, namun di dalam pasal 6 mengatur bahwa untuk melangsungkan pernikahan yang belum mencapai umur 21 tahun harus mendapat izin orang tua (Idrus, 2018).

Apabila calon pengantin melangsungkan pernikahan di bawah usia yang telah diatur dalam undang-undang pihak KUA tidak dapat langsung menikahkan pasangan tersebut, namun bila akibat pergaulan bebas, misalnya calon pengantin sudah hamil masih memberikan kemungkinan untuk menyimpang dengan meminta dispensasi kepada Pengadilan Agama atau pejabat lain yang berkompeten dalam hal ini, sehingga pernikahan dapat dilaksanakan (Idrus, 2018).

Jadi sesuai undang-undang menurut pendapat saya bila pernikahan dilakukan di bawah umur 20 tahun berarti peran orang tua masih ada, sebaiknya orang tua memberikan edukasi, karena dalam rencana suatu pernikahan peran orangtua sangat dominan, selain faktor jodoh dan keinginan anak itu sendiri, jika orang tua telah memberikan edukasi pada anaknya, hingga anak dapat memutuskan untk menikah dengan usia yang matang, tidak perlu izin orang tua lagi. 


\section{Kebijakan Integral Usaha Pendewasaan Usia Pernikahan pada Remaja Etnis Melayu di Kota Palembang}

Mempersiapkan pribadi yang dewasa sangat diperlukan dalam membangun keluarga yang harmonis dan sejahtera, terutama kehidupan keluarga yang matang dan mapan yang merupakan dambaan setiap pasangan yang membina keluarganya. Dengan pembinaan nilai-nilai moral dan optimalisasi fungsi kekerabatan melalui fungsi keagamaan, fungsi sosial budaya, fungsi cinta, fungsi perlindungan, fungsi reproduksi, fungsi sosialisasi dan pendidikan, fungsi ekonomi, dan fungsi bina lingkungan diharapkan dapat mencegah terjadinya pernikahan dini sebagaimana Peraturan Pemerintah Republik Indonesia Nomor 21 Tahun 1994 tentang Penyelenggaraan Pembangunan Keluarga Sejahtera. Dengan penjelasan sebagai berikut:

a. Fungsi Religi: Keluarga menjadi wadah bagi anak untuk mengenal agamanya, di mana nilainilai takut akan Tuhan ditanamkan dan dikembangkan yang akan mempengaruhi cara anak bergaul dengan teman-temannya, terutama lawan jenis sehingga tidak terjadi. mengambil tindakan yang salah dalam interaksi sosial. Memupuk rasa takut akan Tuhan harus ditanamkan sejak masa kanakkanak, agar ketika memasuki usia remaja ada fondasi yang kuat saat bergaul (Waleleng \& Maitimo, 2018).

b. Fungsi Sosial Budaya: Sebagai makhluk sosial, remaja membutuhkan orang lain untuk berinteraksi, terutama dengan teman sebayanya. Namun dalam mengembangkan sifat sosial dengan orang lain harus ada batasan sesuai dengan norma dan aturan ketimuran. Ada batasan dalam bersosialisasi agar tidak terpengaruh oleh hal-hal negatif. Harus bisa menolak seks bebas, narkoba, pernikahan dini (Waleleng \& Maitimo, 2018).

c. Fungsi cinta kasih: Semua anggota keluarga harus saling memberi dukungan, perhatian dan kasih sayang. Cinta untuk orang lain, terutama terhadap lawan jenis, pasti ada batasnya. Perlu batasan untuk mengungkapkan cinta (Waleleng \& Maitimo, 2018).

d. Fungsi Perlindungan: Keluarga merupakan tempat berlindung bagi setiap anggota keluarga untuk memberikan rasa aman, tenang dan tentram. Sehingga jika ada masalah, anggota keluarga bisa saling mendukung untuk dicarikan solusinya. Remaja yang bermasalah tidak mencari solusi kepada orang lain, yang mungkin memberikan solusi yang salah (Waleleng \& Maitimo, 2018).

e. Fungsi Reproduksi: Salah satu tujuan pernikahan adalah untuk memiliki keturunan, namun lebih aman melakukan pernikahan pada usia yang tepat, yaitu di atas 20 tahun untuk wanita dan di atas 25 tahun untuk pria (Waleleng \& Maitimo, 2018).

f. Fungsi Sosialisasi dan Pendidikan: Orang tua memainkan peran penting dalam mendidik remaja tentang risiko pergaulan bebas, pernikahan dini dan penggunaan obat-obatan terlarang. Penjelasan tentang fungsi organ intim hingga alat kontrasepsi bukan lagi hal yang tabu untuk dijelaskan. Penjelasan awal dari orang tua sebaiknya dilakukan agar remaja mendapatkan ilmu yang benar oleh orang yang tepat (Waleleng \& Maitimo, 2018).

g. Fungsi Ekonomi: Mengatur sumber pendapatan untuk memenuhi kebutuhan keluarga. Faktor ekonomi menentukan keharmonisan keluarga. Pernikahan dini akan menyebabkan pasangan belum siap secara ekonomi sehingga kehidupan rumah tangga 
masih bergantung pada orang lain dan rawan konflik (Waleleng \& Maitimo, 2018).

h. Fungsi Lingkungan: Remaja diarahkan untuk berperan menjaga kebersihan lingkungan sekitarnya. Kebiasaan menjaga kebersihan lingkungan ini diharapkan sejalan dengan kebiasaan menjaga kebersihan diri, terutama kebersihan organ intim agar terhindar dari penyakit (Waleleng \& Maitimo, 2018).

Peran keluarga sebagai unit terkecil dalam masyarakat juga ditegaskan dalam RPJMN 20202024, bahwa ketahanan keluarga inilah yang memungkinkan terciptanya sumber daya manusia yang berkualitas dan berdaya saing. Sejumlah lembaga seperti BKKBN, Kemdikbud, Kementerian Kesehatan, dan KPPPA melalui PUSPAGA (Pusat Pembelajaran Keluarga) memberikan pendidikan bagi keluarga dan orang tua yang menjangkau masyarakat hingga ke tingkat desa. Tantangan program yang ditujukan kepada orang tua antara lain kurangnya partisipasi program bersifat sukarela - dan sulitnya menjangkau orang tua yang bekerja secara intensif di bidang tersebut. Oleh karena itu, salah satu strategi bagi orang dewasa juga akan mencakup penguatan kapasitas dan kesadaran orang dewasa (orang tua, guru, dan masyarakat/guru agama/adat) dalam berkomunikasi dengan remaja terkait masalah pernikahan dan kesehatan reproduksi, serta bersikap berani. Dengan tegas untuk mengingatkan orang agar tidak menikah di usia muda.

Kebijakan pengendalian dan pencegahan pernikahan usia dini adalah dalam rangka untuk mencapai tujuan akhir dari kebijakan itu sendiri,yaitu mencapai kesejahteraan bagi masyarakat. Masalah kebijakan hukum pernikahan tidak hanya sebatas membuat atau menciptakan suatu peraturan perundang-undangan, kebijakan memerlukan pendekatan yang menyeluruh yang melibatkan berbagai disiplin ilmu serta kenyataan di dalam masyarakat sehingga kebijakan hukum yang digunakan tidak keluar dari konsep yang lebih luas yaitu kebijakan sosial. Kebijakan pengendalian dalam usaha pendewasaan usia pernikahan pada dasarnya merupakan bagian integral dari politik sosial yang harus mengarah padatercapainya tujuan kebijakan sosial yaitu "social welfare" atau untuk mencapai keseimbangan (equality). Secara sederhana tujuan kebijakan usaha pendewasaan usia pernikahan itu sendiri adalah untuk menuju kesejahteraan masyarakat (Arief, 2011). Selengkapnya dapat dilihat pada gambar 1.

Gambar 1. Kebijakan Pendewasaan Usia Pernikahan

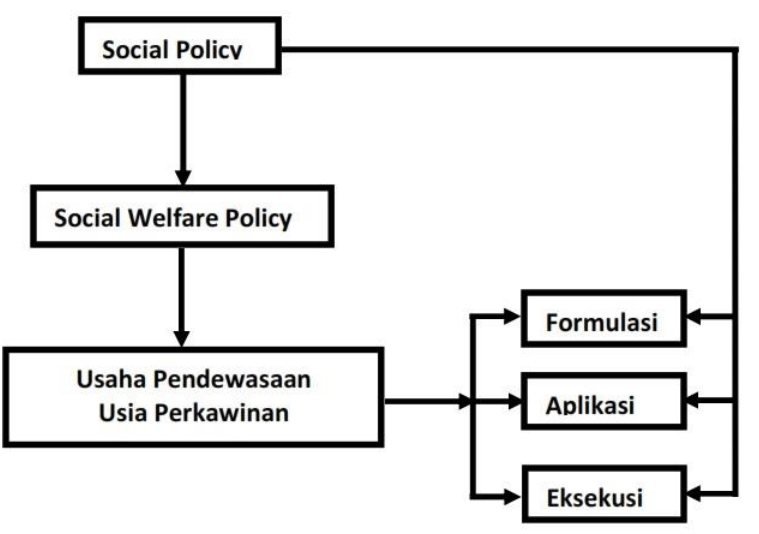

Dari uraian di atas, dapat diartikan bahwa upaya pemerintah untuk mengurangi pernikahan usia muda sangat ditentukan oleh penguatan kerjasama dengan lembaga legislatif, eksekutif, dan yudikatif, serta melibatkan partisipasi masyarakat, media dan dunia usaha. Sinergi antar pemangku kepentingan diharapkan dapat mengurangi praktik pernikahan secara lebih terstruktur, holistik, dan integratif di Indonesia.

Pemerintah telah menyusun Strategi Nasional Pencegahan Pernikahan di Usia Muda 
yang dapat dijadikan acuan dalam upaya percepatan Indonesia Layak Anak (IDOLA) tahun 2020 dan Indonesia Emas tahun 2045, semua program terkait isu pencegahan anak. pernikahan tersedia untuk kementerian lembaga yang menargetkan intervensi kesehatan reproduksi, remaja, keluarga, dan wanita. Dengan demikian, KPPPA, Kementerian Agama, BKKBN, Kementerian Pendidikan dan Kebudayaan, dan Kementerian Kesehatan menjadi lima kementerian/lembaga utama yang memiliki program pencegahan pernikahan anak. Namun, dalam strategi Komunikasi, Informasi dan Edukasi (KIE) lima kementerian /lembaga terkait kesehatan reproduksi, keluarga, dan pernikahan anak, belum ada bukti yang cukup tentang adanya koordinasi atau kolaborasi.

\section{Kesimpulan}

Penelitian ini menyimpulkan bahwa pertama, fenomena pernikahan dini di Indonesia mengalami peningkatan dari tahun ke tahun. Secara khusus di kota Palembang, di kecamatan Seberang Ulu I pada tahun 2018 terdapat 139 kasus dari 1160 Pasangan yang melakukan pernikahan, tahun 2018 terdapat 197 kasus dari 1229 pasangan. Sedangkan di kecamatan Ilir Timur II pada tahun 2017 terdapat 65 kasus dari 1092 pasangan, dan pada tahun 2018 terdapat 81 kasus dari 1111 pasangan, sedangkan di kecamatan Sukarame pada tahun 2017 terdapat 83 kasus dari 1040 pasangan dan tahun 2018 terdapat 83 kasus dari 1259 pasangan. Kedua, para tokoh masyarakat berpandangan bahwa pernikahan merupakan perintah Allah Swt. dan perintah Rasul. Dalam Islam, batas usia diperbolehkannya menikah tidak dijelaskan secara rinci tetapi Islam menyaratkan adanya kesiapan fisik dan mental. Dan ketiga, dengan pembinaan nilai-nilai moral dan optimalisasi fungsi kekerabatan melalui fungsi keagamaan, sosial budaya, cinta, perlindungan, reproduksi, sosialisasi dan pendidikan, ekonomi, dan bina lingkungan diharapkan dapat mencegah terjadinya pernikahan dini. Selanjutnya upaya pemerintah untuk mengurangi pernikahan usia muda sangat ditentukan oleh penguatan kerjasama dengan lembaga legislatif, eksekutif, dan yudikatif, serta melibatkan partisipasi masyarakat, media dan dunia usaha secara terstruktur, holistik, dan integratif di Indonesia.

\section{Daftar Pustaka}

Abdulah, M. A. (2020). Wawancara. Ketua FKUB Palembang.

Alif, M. (2020). Komunikasi antar budaya dalam tata cara pernikahan adat Minangkabau di Kota Banjarbaru (Studi Kasus Tiga Pasangan Berbeda Etnis Antara Etnis Minangkabau dengan Etnis Banjar, dan Jawa). Meta Communication Jurnal Ilmu Komunikasi.

Arief, B. N. (2011). Bunga Rampai Kebijakan Hukum Pidana. Kencana.

Fahrizal, R. (2020). Wawancara. Tokoh Agama Kota Palembang.

Guilbert, N. (2013). Early marriage, women empowerment and child mortality: married too young to be a good mother. Selected Paper Presented in the DIAL Development Conference" Institutions and Development" June 27th-28th.

Hadjar, S. (2020). Wawancara. Kepala Dinas PPPAPM Kota Palembang.

Idrus, A. A. (2018). Wawancara. MUI Provinsi Sumatera Selatan.

Indonesia baik. (2020). Masih Banyak Wanita Indonesia Nikah di Usia Dini.

Irfan. (2019). Wawancara. Bimas Kemenag Kota Palembang.

Iskandar, S. (2021). Wawancara. Tokoh Masyarakat Palembang.

Jeki, S. (2018). NILAI FAEDAGOGI PERKAWINAN ETNIS MELAYU DI DESA SAKO KECAMATAN RAMBUTAN KABUPATEN BANYUASIN. Kalpataru: Jurnal Sejarah Dan Pembelajaran Sejarah, 2(1), 69-78.

Kadarisman, Y., \& Asmidar, A. (2015). Perubahan Tradisi Perkawinan Etnis Melayu di Desa Bantayan Hilir Kecamatan Batu Hampar 
Kabupaten Rokan Hilir. Riau University.

Kalsum, U. (2020). Wawancara. Pengurus Majelis Taklim Alhidayah dan Tokoh Persis Palembang.

Leny. (2020). Percepatan Pembahasan Tindak Lanjut Putusan Mahkamah Konstitusi Atas Perubahan UU Perkawinan No. 1 Tahun 1974. Seminar Nasional.

Malasari, Y., \& Darmawan, C. (2017). Budaya Adat Pengantin Melayu Riau Dalam Pengembangan Budaya Kewarganegaraan. HUMANIKA, 24(1), 11-23.

Pedia, W. (2019). Melayu Palembang. $9789067181,14927036$.

Rahmawati, D. (2020). Pernikahan anak di Indonesia peringkat dua ASEAN. Lokadata.

Ramadhan, I., \& Noor, A. S. (2015). Asimilasi Perkawinan Arab-melayu Kampung Arab Kelurahan dalam Bugis Pontianak. Jurnal Pendidikan Dan Pembelajaran Khatulistiwa, 4(4).

Rifiani, D. (2011). Pernikahan Dini Dalam Perspektif Hukum Islam. Journal de Jure, 3(2), 125-134. https://doi.org/10.18860/jfsh.v3i2.2144

Rospita. (2020). Wawancara. Korwil KB IT II.

Saifurrahman. (2020). Wawancara. Tokoh Agama Kota Palembang.

Satriyandari, Y., \& Utami, F. S. (2020). Pernikahan Dini Usia Remaja. Universitas' Aisyiyah Yogyakarta.

Statistik, B. P., \& UNICEF. (2016). Kemajuan yang tertunda: analisis data perkawinan usia anak di Indonesia. Jakarta: Badan Pusat Statistik.

Supriyadi, D. (2011). Fiqh Munakahat Perbandingan (dari tekstualitas sampai legislasi). Bandung: CV Pustaka Setia.

Triningsi, S. P. (2020). Wawancara. Korwil KB SU I.

Waleleng, G. J., \& Maitimo, B. I. (2018). FUNGSI KELUARGA DALAM MENCEGAH PERNIKAHAN USIA DINI SEBAGAI UPAYA MENEKAN TINGKAT FERTILITAS DI KOTA MANADO. Acta Diurna Komunikasi, 7(4).

Wikiwand. (2020). Suku Palembang.

Yuhanis, S. (2020). Wawancara. Korwil KB IT II. 